\title{
Assessment of Women Participation in Primary Saving and Credit Cooperatives in Dawuro Zone Essera District, South West Ethiopia
}

\author{
Bekele Tona Amenu Mengistu Mekuria Tona \\ Wolaita Sodo University, Dawro Tarcha Campus P.O.Box, 01, Tarcha, Ethiopia
}

\begin{abstract}
Cooperative is a form of organization where voluntary associated together as human being on the basis of equality for the promotion of economic interest of themselves. The study would be conducted to assess cases that hinder women participation in SACCCOs in case of Essera woreda. Women has face many problems in order to participate in cooperative society, division of work and the patriarchy are the source for hindering factors for women to participate in cooperative. The general objective of this study was to assess factors that hinder women participation in cooperatives. The study used both primary and secondary data the primary data were collected from interview, questionnaire and group discussion. The secondary data was collected from member's loan books, members saving books, members by low, the Essera Woreda Cooperative Promotion Office (CPO) document and other research work. This data was analyzed by using table, percentage and graph. In order to SACCO for economic benefit in saving and credit cooperative society face the problems in adequate financial structure, low attitude members about saving and loan use and lack of awareness. These situations have the opportunities of cooperative like, members of Essera saving and credit cooperatives are expected to provide them with a wide range of saving and credit to be used in everyday living and members hope to benefit from saving and credit cooperatives in respect of fair prices, high quality products and reliable services. The result of the study revealed that most of the respondents saved their money on their saving and credit cooperative society after they join. This indicates that the saving performance of the members was increased. Federal cooperative agency should pay attention continuously supervising of SACCO as they many peoples in providing loan as well as saving services and they are one of the financial services providers that highly contribute for the outreach of financial services for the memberships.
\end{abstract}

Keywords: SACCO, women, Economy, Essera

DOI: $10.7176 /$ RHSS/10-5-04

Publication date:March $31^{\text {st }} 2020$

\section{INTRODUCTION}

\subsection{Background of the Study}

The history of cooperative dominated by rural example probably because of the nature of rural life the history of modern cooperative raised to impact of industrial revolution that brought immense wealth to the capitalism and (Tiwar, 1976) Open to all person able to use their service and willing to accept the poverty to an organized labor. According to verakumer (2003) cooperative are voluntary organization responsibility of membership without generally social, political or religion discrimination. Cooperative is an autonomous association of person united voluntarily to meet their common economic, social and cultural need and aspiration through a jointly owned and democratically controlled enterprise (ICA) According to international cooperative alliance (ICA). A cooperative is an autonomous association of person united voluntary to meet their common economic, social and cultural need and aspiration through a jointly owned and democratically controlled enterprise (DR.KRISH NASWAMI, 2000 pp17).Cooperatives are not new phenomena in the world. The contribution of cooperative for development has been scholars thought in the 1980 the contribution of cooperative for developing world was 20 times greater than of external investment (www.ica.org). The case of participant in cooperative in this day ICA announced that there are around 800 million people are involved in this sector. In Canada from 3 people, in USA from 4 and in KENYA from 5 people, 1 is a member of cooperative. In Africa from 1970 to data there has been an increasing desire to create an environment in which women are afforded calls opportunities to participate In and benefit from cooperative development efforts. Two distinct objectives result from the above policy, namely to integrate gender concern in to all cooperative programs and to bring about specific improvement in women legal rights. The attainment of this objective has meet serious obstacle due to the strong tradition and customer proactive that has also greatly influence the law making process in the country. It is a living reality that customer law relates women to inferior position and this tied up with the general development of society (Tilahun Haile June 2015).

The value of self-help, mutual responsibility, equality and equity are held common by all cooperators. But even though cooperatives may policies of equity and equal opportunity for women and men, their practice may differ, true equality in reality may not exist. Women contribute to significantly to the agricultural sectors and hence to national economy nearly all countries in the world. The percentage of women member in agricultural 
cooperatives compared to men's, is notably lower. Women participation is also practically none existent in cooperatives at decision making (Dr. Krishna swami, 2000, pp 67-70). When we come to particularly in Ethiopia, there is low participation of women in cooperatives and also other different types of institution because of cultural be live women are still marginalized specially in rural area where cooperative are dominated by male. Women member ship in cooperatives is not high and practically no women are found in leader ship position. As a result of this the researcher tried to investigate the problem of women to participate I cooperatives and it will gives a solution to the problem.

\subsection{Statement of the Problem}

It is obvious that, in many society women's are very important power full and influential. It is clear that women face a number of problems in developing country in general and in Ethiopia in particular. This socio cultural situation of the country that are face with gender division of labor and the patriarchy are the source for the disadvantaged position of women which is characterized by harm full traditional proactive, un employment, lack of formal education, lack of health facility and so on.(Members loan book ,members saving books ,members by law and Annual report). Women participate in different economic activities of livelihood such as in agriculture, trade, industry and the like. However; they face many challenges as mentioned before. Women accessing in saving and credit cooperatives is very important because, it increase social acceptance, economic strength and they can easily participate each other's in different situation. In order to empower women economically and to bring them in decision making position at the house hold levels in the community at large is compulsory in every aspect of life, political economic and social spheres, however, it is challenging in line with this, the main concern of this study was to make an assessment of factor that hinder women's participation in cooperatives.

\subsection{Research Question}

1. What does it look like the attitude of peoples towards women participation in cooperatives?

2. What are the major factors affecting women's participation in SACCOs?

3. What are the roles of governmental and non-governmental organizations in supporting women's participation in SACCOs?

\subsection{Objectives of the study}

\subsubsection{General Objectives}

The main objective is to access women participation in primary saving and credit cooperatives

\subsubsection{Specific Objectives}

1. To investigate the attitude of people towards women participation in saving and credits cooperatives

2. To identify the major factors affecting women's participation in primary SACCO.

3. To identify the role of governmental and non-governmental organizations in supporting women's participation in primary cooperatives

\subsection{Significance of the Study}

The study would have different merits on different direction among this

$>$ this study important to government to indicate women socio economic status in the community

$>$ The study would be important to NGO and governmental organization which work on saving and credit cooperatives could use this research as feedback and improve their activity in the future.

$>$ It is also important to further study for other researcher who needs to work in the study area.

\subsection{Scope of the Study}

Specifically the study is limited to Essera woreda and the study covered factors affecting women participation in cooperatives. But due to financial and time constraint the study would not cover all types of cooperatives in the woreda, it is only limited to factors that hinder women participation in saving and credit cooperatives.

\subsection{Limitation of the Study}

Of course, it is clear that any research would not be free from certain limitations. One of the most limitations that the researcher may face during the study conduct will be financial constraints. Some other problems will be also related to time and material constraints, no access to internet available, transport difficulty to collect the data, and lack of sufficient literature on topic to be studied.

\section{RESEARCH METHODOLOGY}

\subsection{Background of the study area}

The study was conducted in Southern Nations, Nationalities and Peoples Regional State (SNNPRS) of Ethiopia in the Esera woreda of Dawro zone, southwestern Ethiopia. The capital of Esera is Bale. It is situated in the Omo 
basin located $323 \mathrm{~km}$ and $670 \mathrm{~km}$ far from Hawassa and Addis Ababa which are capital cities of the Southern Peoples Region and Ethiopia, respectively. The woreda shares boundary with Mareka woreda in the east, Tocha woreda in north, Konta special woreda in the west, Loma woreda south east and Gamu gofa zone in the south.

According to 2007 population and housing census population of the district had an estimated population of 82,218 of which 41,762 male and 40,456 female. The district has 29 kebeles. The area is topographically rugged. The Woreda covers total area of 106021.26 hectares and lies between $6^{\circ} 38^{\prime} 00^{\prime \prime}-7^{\circ} 6^{\prime} 00^{\prime \prime}$ degree north latitude and $36^{\circ} 38^{\prime} 00^{\prime \prime}$ to $37^{\circ} 13^{\prime} 00^{\prime \prime}$ degree east longitudes, with an elevation ranging 501-2500m. Regarding the Agro-Ecology, $47 \%$ was tropical, $32 \%$ was Subtropical and $21 \%$ was temperate.

The annual mean temperature ranges between 15.1 to $27.5^{\circ} \mathrm{c}$. The rainfall was a bimodal type, the short rainy season was between (February to March) and the long between (May to September). The average annual rainfall ranges from 1201 to $1800 \mathrm{~mm}$. According to the land utilization data of the area, $38.4 \%$ is cultivated land, $13.39 \%$ grazing land, $16.81 \%$ forest bushes and shrub land, $17.09 \%$ cultivable and 14.31 is covered by others. The livestock resource of the woreda was estimated to be 313,094 cattle, 113,554 sheep, 45,703 goats, 7,081 horses, 1,934 mules, 5,064 donkeys, and 157,996 chicken and 28,557 traditional hives Central Statistics Agency (CSA, 2006).

\subsection{Research design}

This research type of the design followed descriptive form of design. The main focus on this study is assessment of factors that Assessment of Women Participation in Primary Saving and Credit Cooperatives in the case of Essera primary saving and credit cooperatives.

\subsection{Target population}

Target population primary saving and credit cooperatives society have total members 300 females. For this study respondents are 30 or $10 \%$ of total study females were selected randomly sampling techniques. This means that every members' cooperative society has in any case approximately a 1 in 10 chance of being selected using this method. Further, all combinations of 30 members' cooperative society have the same probability of selection.

\subsection{Sample Techniques}

In order to collect wide range of and in information from the selected participant, the researcher selected respondent by random sampling techniques. The total numbers of women who are benefited by cooperatives in the woreda are approximately 300 . Among these the researcher selected 30 of them by random sampling techniques and purposive sampling techniques.

\subsection{Sampling size}

For this study respondents are 30 females were selected randomly from population 300 (member of the society). Who selecting by using sampling random sampling techniques. This means that every members' cooperative society has in any case approximately a 1 in 10 chance of being selected using this method. Further, all combinations of 30 members' cooperative society have the same probability of selection.

\subsection{Method of Data Collection}

Both primary and secondary data were collected for the study under consideration. Primary data were collected from sample respondent through open-end and close end questionnaire. Also direct observation and interview method of data collection was employed while collecting primary data from key information's and sample respondents respectively. Secondary data was collected through review of some documents and files (published and unpublished).

\subsection{Types and source of data}

The type of data was used in the study under consideration was both primary and secondary data. The source of data was both primary and secondary sources. Primary data source includes: -information and sampled respondents' secondary data source include. Some filed, reports pestered materials and other materials (published and unpublished).

\subsection{Method of Data Analysis Presentation}

The raw data was collected from different sources were analyzed in terms of the study objective already stated or designed previously. The analysis of the data was employed using both the quantitative and qualitative methods. To analyze the quantitative data different techniques like tables with number and percentage was used. The qualitative data (the data which was collected through interview) was analyzed using narration method. The finding of the study was presented using different techniques. Generally, the results were presented using statistical tools such as, tables, bar graphs, pie charts and percentages. 


\section{RESULTS AND DISCUSSION}

The data which was collected from the study area was analyzed and presented under this chapter which appeared under the topic result and discussion. The data were about the Women Participation in Primary Saving and Credit Cooperatives in Dawuro Zone Essera District.

\subsection{Demographic information of the respondents}

This section summarizes the most important background characteristics of the 30 sampled females and their households in study area covered by the study.

\subsubsection{Age}

Most females were 40 years and above old in the present study shows. The mean and median ages of the female heads of households in study area covered by this study were found to be 47.6 and 45 years respectively. Table below shows the age distribution of female heads of households by five year age groups and current place of residence (Wereda/Kebele).

Table 1. Age Composition of Female Heads of Households

\begin{tabular}{lll}
\hline Age group of the respondents & Frequency & Percent \\
\hline $15-19$ & 1 & 4.29 \\
$20-24$ & 2 & 7.14 \\
$25-29$ & 3 & 9.71 \\
$30-34$ & 4 & 11.43 \\
$35-39$ & 5 & 12.86 \\
$40-44$ & 5 & 16 \\
$45-49$ & 4 & 14.57 \\
$50-54$ & 3 & 10.86 \\
$55-59$ & 2 & 8.3 \\
$60-64$ & 1 & 3.71 \\
$65+$ & 0 & 1.14 \\
\hline Total & 30 & 100 \\
\hline Sources: & &
\end{tabular}

Sources: Field survey (2019)

As it can be seen from the table in very high and low age group there is less female household number. The highest number found in age group $40-44$ which is 37 or $16 \%$ of total respondents.

\subsubsection{Education Status of Household}

Table 2. Educational status of household heads

\begin{tabular}{|l|l|l|}
\hline Educational status & Frequency & Percent \\
\hline Illiterate & 8 & $28.0 \%$ \\
\hline Write and read & 5 & $17.0 \%$ \\
\hline Primary school & 15 & $50.0 \%$ \\
\hline Secondary school & 2 & $7.0 \%$ \\
\hline Total & 30 & $100.0 \%$ \\
\hline
\end{tabular}

Sources: Field survey (2019)

From the survey results, better-educated households have more realistic perceptions about SACCO, the way to gain economy.

\subsubsection{Household size and composition}

The research has tried to find out the number of members in the households covered by the study. Results are summarized and presented in below.

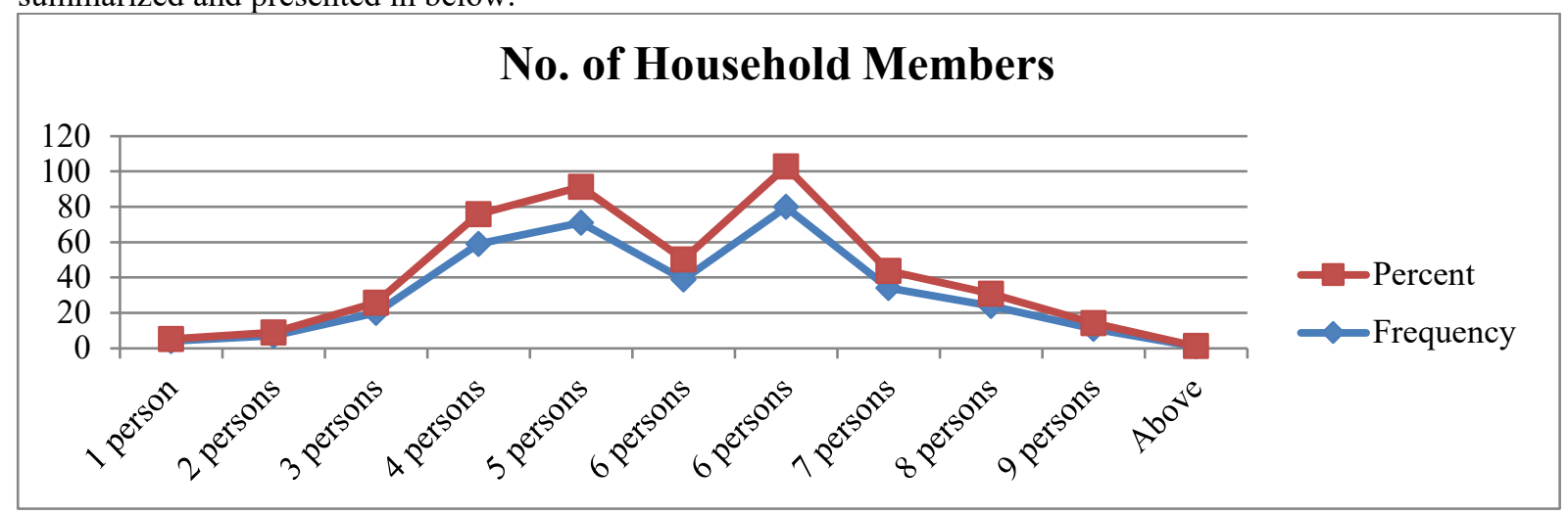

Figure 2. Number of Household Members 
As figure above shows, the majority of female headed households in almost all respondents have 3 to 7 members. From the total females covered by the study $5.71,16.86,20.3$, and 22.86 percent have $3,4,5$ and 6 members respectively. That means in each house there many member of household that are taken by one female house hold head. As discussion with focus group and key informant interview indicated most house hold headed females are engaged in different works that require strong and labor intensive like tilling by oxen to fulfill the requirements of their household members.

\subsubsection{Marital status}

The marital status of the respondents is that almost all respondents who were interviewed married. Among the respondent I didn't come up with unmarried widowed or divorced unfortunately. A woman who has lost her husband can marry to anyone else.

3.1.5. Livelihood strategies of respondents

Table 3. Source of Cash Income for the respondents

\begin{tabular}{lll}
\hline Major Sources of Income & Frequency & Percent \\
\hline Agriculture & 15 & 50 \\
Bamboo products & 6 & 18.34 \\
Livestock production & 5 & 16.66 \\
Honey & 2 & 6.66 \\
Sale of fire wood & 1 & 3.33 \\
Governmental worker & 1 & 3.33 \\
Charcoal & 0 & 1.66 \\
Total & 30 & 100 \\
\hline
\end{tabular}

Source: Field survey, 2019

All $(100 \%)$ of the respondents had more than one sources of income table above. Households in the study area were engaged in a variety of farm and off-farm activities. However, the major income sources for the households were agriculture (crops, vegetables and livestock), bamboo production and production of other tree products (pole and fuel-wood). Other limited sources of income were wage-labor, petty trading and beekeeping. As table above indicates, the study population has different sources of income from agriculture up to bamboo products. The target of this study was bamboo and it has great income role on the study community as indicated above 18.34 percent of the respondents depend on different bamboo products for their livelihood. The agricultural activity mentioned here includes mixed farming, where crops/vegetables and livestock were managed in combination. Main crops cultivated were barley, beans, peas, onion, cabbage, maize, coffee and "enset".

\subsection{Membership Duration of the Respondents in the SACCOs}

Years of involvement in SACCOs determine the level of participation. In addition to that, as membership duration increased, the women members acquired better knowledge about saving and credit cooperative objectives, functions and management skill and this leads the women members to participate actively.

As depicted in table 8 , and the majority of the women member which $49 \%(n=15)$ have been the member of the cooperative for less than three years while $35.5 \%(\mathrm{n}=10)$ of them have a membership ranging between from three-six years and, $15.5 \%(\mathrm{n}=5)$ of them duration more than six years of membership. In this regard, a greater majority of the respondents have participated recently in the cooperative which were less than three years.

Table 4. Membership duration of respondents

\begin{tabular}{|l|l|l|}
\hline Membership in years & Frequency & Percent \\
\hline $1-3$ & 15 & 49 \\
\hline $4-6$ & 10 & 35.5 \\
\hline Above 6 & 5 & 15.5 \\
\hline Total & 30 & 100 \\
\hline
\end{tabular}

Source: Own Field Study Result, 2019

\subsection{Level of Participation of Women in Saving and Credit Cooperatives}

\subsubsection{Participation of women in General Assembly and Other Committees}

General assembly is the total member of the society and is the supreme organ of the society. Every type of society from primary level to the apex level has its own general assembly. The general assembly of a society shall meet at least once in a year. The power and duties of the general assembly is passing decision after evaluating the general activities of the society, approve and amend the by- law and internal regulation of the society, elect and dismiss the member of management committee, control committee and other committee, determine the amount of share, decide on how the annual profit of the society is distributed, give decision on audit report, hear work report and give proper decision, decide that a society either be amalgamated or divided, approve the annual work plan and budget, and decide any issue submitted by the management committee and other committee(proclamation 147/98 
article 20).

Every society shall have management committee which is accountable to the GA and whose member and manner of election to be determined in the bye-law of the society. The power and duties of the management committee shall be, maintain the minute of a meeting in writing, maintain the document, and books of account of the society, prepare the annual work program and budget of the society, implement up on implementation, submit report to the GA on the activities of the society(proclamation 147/98 article 23 and 24).

Cooperative based on their nature of business transaction and service delivery can establish various type of committee. According to article 27 in proclamation no 141/97, cooperative has a full power to establish sub committee based on their importance and requirement. Since the selected cooperative was SACCOs credit committee was mandatory to carry out the following activities: to sign in cooperative voucher, cheques, to prepare monthly reporting system, to make purchasing and selling order, prepare financial statement quarterly, semi annually and annually, follow up the collection of debts, facilitate the member payment of patrons, prepare financial performance of cooperative and decide the amount of credit. The society has its own credit committee.

In this study, it was trying to assess the level of women participation at different supreme organ of the cooperative society. This is the participation of women in general assembly, management committees and credit committees meeting that have a power in decision making on social and economic activities. Based on this, the levels of participation in different committees have been assessed and the following results have arrived. As indicated in table below, the level of women participation in general assembly is below $(50 \%)$. Only $(21.7 \%)$ of the respondents were attending the general assembly frequently. In management and credit committees, the participation of the women respondents were extremely low which were $(6.6 \%)$ and $(12.3 \%)$ at the highest level respectively. From this, it is possible to point out that, the level of women participation in the different committees was low.

Table 5. Participation of women in different SACCOs committees

\begin{tabular}{|l|l|l|}
\hline Attending in general assembling meeting & Frequency & Percent \\
\hline lower & 10 & 34.0 \\
\hline Moderate & 13 & 44.3 \\
\hline Very high & 7 & 21.7 \\
\hline Total & 30 & 100.0 \\
\hline
\end{tabular}

Source: Own Field Study Result, 2019

3.3.2. Participation of women in Decision Making

Decision making is in this study refers to the roles of the women in deciding on resource in their respective households after they joining the saving and credit cooperatives and got some assets from it to improve their economic status and wellbeing. The study further inquired if there has been any change in the decision making roles of the women in their respective households. The questions they responded to include (among other issues) if there has been any change in deciding on income and expenditures of the household, child schooling, child marriage, responsibilities on household chores as well as contraceptive use.

The power of decision making (Decision on loan taking, \& utilization, decision on children education, on land use, buying $\mathrm{HH}$ asset, purchasing agricultural inputs, $\mathrm{HH}$ expenditure, usage of own earning, on social or religious ceremony and on use of contraceptive) of women on average were slightly increased after they joined the SACCO from $10 \%$ to $15 \%$.

\subsubsection{Participation of women in Taking Credit/Loan}

Before the establishments of the micro-finance institution like SACCOs, Omo and Commercial bank, history has revealed the suffering of the community by the hand of money lenders. But now and even at remote rural area through SACCOs, members can get micro- credit of small and large amount to create or to start small trade, business and other agricultural activities. Moreover SACCOs are minimizing and in some area abolished the money lenders.

Members of the saving and credit of Essera district have got access of credit as a primary service. The women members have equal opportunity to got access of credit within the cooperatives.

The existing SACCOs are expected to contribute in improving living standards of their Members. Because the small holders in the urban as well as the rural area do not have access to financial institutions like Omo or Commercial Banks due to lack of collateral to secure the loan to be granted. Hence, SACCOs should play the greatest role in realization of the need for financial services for the poor society to promote their living standards. In this regard, the experience of credit/loan taking was analyzed below.

As indicated in table below, (74.5\%) of the women have experience in taking loan from any other financial institution before joining to the SACCOs. But, after joining the RUSACCO only (48\%) of the women were participating in taking loan from SACCOs which is less than (50\%).

Even though, the numbers of loan participants were too small, those who got the access (96.4\%) have improved their income after joining SACCOs. 
Table 6. Participation of women in taking credit/loan

\begin{tabular}{|l|l|l|l|l|}
\hline \multirow{2}{*}{ Participation } & Yes & No \\
\cline { 2 - 5 } & Freq & Per (\%) & Freq & Per (\%) \\
\hline Experience in using credit from any institution & 22 & 74.5 & 8 & 25.5 \\
\hline Access of loan from SACCO? & 14 & 48.18 & 16 & 51.82 \\
\hline Monitoring of the loan by the committee or other & 24 & 81.1 & 6 & 18.9 \\
\hline Utilization of loan by yourself & 23 & 77.4 & 7 & 22.6 \\
\hline Default of loan happen or not & 3 & 9.4 & 27 & 90.6 \\
\hline Improving of income after involved in the SACCO & 29 & 96.4 & 1 & 3.6 \\
\hline
\end{tabular}

Source: Own Field Study Result, 2019

3.3.4. Reasons for engaging in Income generating activities

Table 7. Reasons for engaging in Income generating activities

\begin{tabular}{|l|l|l|}
\hline Reasons for engage in income generating activity & Frequency & Percent \\
\hline To have financial independency & 5 & 17.4 \\
\hline To increase the HH income & 23 & 73.6 \\
\hline To escape from domestic chores & 1 & 3 \\
\hline Other & 1 & 4 \\
\hline Total & 30 & 100 \\
\hline
\end{tabular}

Source: Own Field Study Result, 2019

After taking loan/credit, the respondents who have participated in different types of income generating activities (graph 6) are $46.46 \%$ in increasing agricultural productivity including animal husbandry and $22.22 \%$ in small business (shop) at rural area and the rest in different activities.

\subsubsection{Participation of women in saving}

Savings mobilization is becoming a crucial factor of many micro finance institutions. Savings is important for an institution that offers financial services. It provides a source of funds and income. After establishment of SACCOs, saving account creation was common among the members based on their by-laws. Saving deposition takes place mostly on monthly bases. The members should participate either compulsory or voluntary saving. Compulsory is a prerequisite for individuals to be the members of SACCOs. Moreover, the source of fund for cooperative is categorized under owned and borrowed fund. The owned fund is contributed by the members alone. The borrowed fund was issued and accessed from external source. The primary activities of SACCOs were financial services.

To carry out this financial service like loan, cooperative societies encourage their members to deposit more and on time. This implies that members in the cooperatives were participating actively to get service like loan from the deposited money. Generally, by depositing saving the members of SACCOS can receive a market interest rate and dividend from profit of the SACCOs savings as respondents explained.

\section{CONCLUSION AND RECOMMENDATION}

\subsection{Conclusion}

The number of members in SACCOs is increasing from time to time. The factors that could contribute in attracting new members would be low cost of saving and the benefits that former members enjoy such as dividend and easy credit access.

This section summarizes the finding of data analyzed in chapter four of this paper. From the analysis part of the research concerning the identification of activities undertaken by the societies, this saving and credit cooperative carried out many remarkable activities especially in providing loan and saving activities to members.

The study was conducted with a general objective the role of SACCOS on members saving, credit and economic benefit with having three specific objectives.

The first objective deals with the investigation of saving performance of members that concerned with every saving activities of the members including the saving trends of the members and their attitudes towards the voluntary saving.

Hence the result shows that most of the respondents saved their money on their saving and credit cooperative society after they join. This indicates that the saving performance of the members was increased.

The second objective deals with the utilization of credit by members which includes the need of credit by members, purpose of credit and members loan repayment. The result concerned with these shows that members need credit for productive and non-productive purpose. This shows that credit utilization of members is good and the money was invested for the purpose of production and others objectively.

The third specific objective deals with the investigation of liquidity habit of the members. This means that the repayment of loan on maturity date, almost all respondent was repaying the loan on maturity dat. This indicates the members have good repayment performance. One respondent does not repay the loan on maturity date because of low income. Generally, the SACCOS have the role in solving the financial problems of the members and 
improving their living standards of the members. According to this study SACCOS have the role in improving saving, credit and economic benefit of its members.

\subsection{Recommendations}

Based on the finding of the research, the researchers recommended the following points in order to overcome the problems being observed and analyzed from the societies.

* The society managers must be follow and supervise the cooperative society who are the members of saving and credit cooperative society to save their money at SACCOs continuously year to year. This saving and credit cooperative members lake of awareness the benefit of saving activity. So the management body the society and cooperative promotion office sported and gives different training about the economic benefit of saving activity and SACCOS.

* The management body of the SACCOS should give training on members saving activity as members to save some amount of their income of on voluntary saving.

* The management body and members of the SACCOS should follow up by low of SACCO and the members to repay the credit they received from SACCO on maturity date.

* The members of SACCO should have to save enough money in SACCO to get enough money in form of credit.

* The member's in their cooperative should increase from time to time to maximize their enterprise more and income and must increasing economic benefit of the member by different activity of SACCO based on objective of this society and related to saving and credit activity. the management body and members of the society focus on growth of capital or financial condition income generating activity and members efficiently participation in any social and economic activity like credit, dividend and other economic benefits activity of the society.

* Building capacity of cooperative to increase economic benefit of the members must give much attention by the cooperative promotion office and initiating non-governmental organization to support SACCO are the mains to be get great attention by different organization for the development cooperatives and to change living standard of members.

* Finally, Federal cooperative agency should pay attention continuously supervising of SACCO as they many peoples in providing loan as well as saving services and they are one of the financial services providers that highly contribute for the outreach of financial services for the memberships

\section{REFERENCE}

Center for cooperative (2004), working together for strong cooperative. University of Wisconsin, USA.

David Volk, 1998 cooperative management and organization, $1^{\text {st }}$ edition, India.

Eva Majurin, march 2010, how cooperative work for working women in Africa, www, 1 \% org/public/English assessed on may10-12.

Koopmans (2006), starting cooperative; farmers controlled economic initiative $2^{\text {nd }}$, Wageningen (CIA), or Krish Nuswami (2000). Cooperative concept and theory.

Naila Kabeer; the emergency of women as constituency in development, in reversed realities; gender hierarchies in development through, verse, London, 1994 pp1-10.

Oscar r. Zebeau (1985).Credit and self-help group.

T. nhajela 1994, principles, problem and practice $6^{\text {th }}$ edition, Konark publisher, New Delhi.

Yeshiareg Dejene (AFDB), promoting women's economic empowerment in Africa (related research). 